\author{
Lukasz Marzec \\ Jagiellonian University \\ lmarzec@uj.edu.pl \\ ORCID 0000-0002-2553-2711 \\ https://doi.org/10.26881/gsp.2019.3.02
}

\title{
SOME REMARKS ON SEA TRANSPORT AND ITS LEGAL REGULATIONS IN ROMAN LAW ${ }^{1}$
}

Just a cursory look at the map of the Roman Empire shows clearly the importance of transport, for both military and commercial purposes (cf. Rougé, 1966; de Martino, 1980; Cerami, di Porto, 2004). It is well known that the Romans had a road network of 80,000 kilometres, spread over Europe, Africa and Asia (cf. Chevallier, 1976). At the beginning of the Republic, Rome was as large as Cyprus, near 10,000 sq. $\mathrm{km}$. But at the height of the Empire it covered the unbelievable territory of 4.5 million sq. km, becoming as large as the entire European Union today. That was well over four times more than the Kingdom of Poland and Lithuania at its territorial peak in 1634 . The state had a multi-ethnic composition and people were in a continuous movement. Its parts were therefore well connected by means of roads such as Via Salaria or Via Latina. It provided a good infrastructure for local commercial trips, but when it came to long-distance trade transport, only shipping could be fast, efficient and safe enough to meet the needs of the merchants, their bankers and finally customers (cf. Thiel, 1946). The safety of travelling along the inland roads varied with time, but the latrones were often more dangerous than the piraterii. Anybody could be robbed, which even happened to armed soldiers. In 98, young Publius Aelius, a tribune of the XXII Legion and later emperor Hadrian, travelled from Mainz to Cologne and was lucky enough to survive the attack of highwaymen. He lost everything as his milites were unable to defend him (cf. Grünewald, 2004, 21). In 152, Valerius Etruscus, the governor of Numidia

1 This paper is to some extent based on this author's previous article: Marzec (2018). Several issues were revised or added; the paper was delivered at the $2^{\text {nd }}$ International Seminar Roman Maritime law organized by the University of Gdańsk on 10 April 2019. I would like to thank Professor Jacek Wiewiorowski, the head of the Chair of Roman Law in Gdańsk for inviting me to thats most interesting event. 
received a complaint from Varius Clemens, the procurator of Mauretania, who had been robbed and wounded on the way and hardly escaped with his escort (cf. Bryant, 1895).

It is clear that if it had not been for the highly developed shipping, Rome would never have achieved such a dominant commercial position. This was a whole industry which could easily have astonished future generations in the medieval and early modern times. The most important cargo was grain, with the centre in Alexandria, the largest harbour in the ancient world. ${ }^{2}$ Grown in the highly fertile Nile Valley, it was harvested and shipped to Europe, most often to Misenum and Ostia near Rome. This was a massive transportation challenge: 450,000 tonne of grain a year. The modern giant bulk-carrier of the Panamax class (the largest ship to cross the Suez or the Panama Channel), able to carry near 80,000 tonne, would have to make 6 voyages to do it. How large was the ancient grain market? The highest volume in the Vistula grain trade in 1618 hardly reached 250,000 tonne; this is noteworthy considering that the Vistula grain route which ended in Gdańsk was regarded as the world's leading one in the seventeenth century ( $c f$. Mielczarski, 1982, 61-79).

To enable the trade, the Roman fleet had to keep a variety of vessels (cf. Torr, 1894). From the smallest carrying from 70 tonne, the medium-sized from 100 to 200 , and the huge muriophorio with the maximum load of 550 tonne. Those carriers would have been able to take the weight of five Boeing 787 Dreamliners. But the largest was Isis, 55 meters long, with the maximum capacity of 1,200 tonne of grain, enough to feed an entire town for a year. This was not the last word of antiquity, as Ptolemy IV Philopator had a ship able to take 6,500 tonne, and Noah's Ark is calculated to have carried 11,0 thousand tonne (cf. Hölbl, 2003, 133). That was very much if we compare it with Columbus's flagship Santa Maria with its carrying capacity of 200 tonne.

We can only imagine how many ships crossed the Mare Nostrum and the Pontus Euxinus, carrying all sorts of goods and providing very good income for the Roman state (cf. Casson, 1971, 336). Although there were some shipping lines for passengers only, travellers usually had to find cargo ships to take them. ${ }^{3}$ Both ship agents and captains had free places on board and could offer them to those who received their departure passports, having paid a fee to Roman harbour masters. Apart from commercial and regular passenger trips, the elite of the state were frequently travelling for leisure, usually on board of luxurious imperial ships. Greece and nearby islands were the major destination: Cicero, Julius Cae-

2 Many students would arrive in Alexandria to study. It had a large university, discovered by the Polish archaeologists in Komm-el-Dikka. It was able to accommodate up to five thousand students in the mainauditorium and the twenty-two lecture halls at the same time. See Derda, Markiewicz, Wipszycka (2007).

3 Ulpianus wrote about passenger-only ships sailing from Cassiope (Corfu) and Dyrrachium (Durrës in Albania) to Brundisium (Italian Brindisi): D. 14.1.12. All Digest citations are based on Palmirski (2014), the first Polish complete edition and translation of the Digest of Justinian. 
sar, Lucretius, Pompeius, Cato the Younger, Tiberius, Antonius and many others travelled to Rhodos to learn at the school of rhetoric. We should bear in mind that sailing and travelling was not easy at the time. The hope to start the voyage within a reasonable time could not always be fulfilled. The weather was the primary consideration condition, but a captain could not depart if ill-omened birds appeared or somebody had a bad dream. No timetable was therefore followed and much patience was necessary.

The sea freight required an entire body of legal regulations, given how important this branch was for the Roman economy (cf. Meyer-Termeer, 1978; Palmirski, 2008; Benincasa, 2011; Kordasiewicz, 2011). The list of applicable regulations spans almost the entire private law: the organization and status of the cargo company, the relations of co-owners, bankers and loans, including the special maritime loan called foenus nauticum, the security of debts, hiring and employment of the crew (slaves were very rarely admitted to work on ships), hiring a captain (magister navis), the relations between the ship owner (exercitor), the captain and third persons (see Falenciak, 1956; Wiliński, 1960; Wiliński, 1964; Krzynówek, 2000; Żeber, 2003; Wolny, 2007; Służewska, 2007; Benincasa, 2010a; Benincasa, 2010b). Those regulations varied depending on whether the captain was a slave, whether the "ship owner" was the real owner or had just hired the ship from somebody else, and, last but not least, if the ship owner was a pater familias, his son, or finally an emancipated woman sine manu. All those possibilities are seen in the Roman legal practice. ${ }^{4}$ This, however, was not the most important part of regulations, as they pertained rather to internal relations. Shipping goods over the sea could be legally established in two general ways. The first one could be the simple locatioconductio rei, according to which a piece of the deck or a loading place was hired to the merchant who stored his goods there and could only pray for them to reach the destination safely (on this issue see Thomas, 1960, 489). If he or his people would not travel along, anything could happen to the cargo as the captain was only liable for letting them use the place and nothing else. There was no liability in case it was stolen, broken, disappeared etc. - the responsibility extended as far as a place on board of the ship which sailed somewhere. Captains were rather unwilling to assume any more liability. However, if merchants managed to impose locatio-conductio operis, according to which reaching the harbour of destination was necessary to enable payment, their situation became slightly better. ${ }^{5}$ The

${ }^{4}$ Roman law regulated maritime issues in detail. The "Captain" was to take care of the entire ship (D. 14.1.1), they were appointed masters of the ship, they could hire the ship for the carriage of goods or passengers (D. 14.1.3). The ship-owner had all benefits, no matter if he or she were "owners" or just a lease-holders (D. 14.1.15) Either a woman or a slave could be a ship-owner. Captains were appointed by them, or by the already appointed captain (D. 14.1.5). The liability of ship-owners for the captains' obligations was laid down as well (D.14.1.7-12); there was also a detailed definition of what a ship was (D. 14.1.6), a raft also qualified as a ship.

5 With respect to passengers as opposed to merchants, there was a practice of using locatio-conductio rerum vehendarum, probably with the liability limited only to his personal, non-commercial luggage. See Zimmermann (1990), 518. 
captain was paid after delivering goods, or had to return the money if the voyage failed. ${ }^{6}$ This was far better than conductio rei, but merchants were still at risk of losing the money as captains were liable for damages or theft only when a proof of his culpa could be provided by the plaintiff. ${ }^{7}$ It literally meant that if the captain had not been caught red-handed by the merchant, or his collusion with thieves or pirates was not proven, it was impossible to make him pay. There is an account of rather poor reputation of sailors (as well as inn-keepers and stable-keepers). Ulpianus tried to explain the situation by quoting Pomponius, in whose opinion the praetor wanted to warn them against dishonesty, because cheating was a common practice. ${ }^{8}$ This was a serious barrier for possible investors or creditors if we bear in mind that a similar legal situation applied to inn or stable owners, who kept merchants' goods, horses, mules and carriages. As a result, there was a serious gap in the law which hampered efficient development of the sea and land commercial transport. There was a great necessity to create an instrument to help those who lost their cargo but the carriers refused liability. A modern case refers to "common carriers" who have a strict type of liability as long they are common, which means they offer service to everyone for money (see Zimmermann, 1990, 523). The praetor's edict De nautae was a real revolution on the market, shifting the contractual liability from culpa to custodia, with an invaluable modern effect which may be truly called consumer protection, even if most of those contracts were business to business (on the edict and relevant literature see Földi, 1993). We have a direct reference from Ulpianus: D. 4.9.1 pr. Ulpianus libro quarto decimo ad edictum: (...) Ait praetor: nautae caupones stabularii quod cuiusque salvum fore receperint nisi restituent, in eos iudicium dabo. It was a milestone in the history of maritime and transport law. Now the merchant had not only actio locati, but also much more powerful actio de recepto, according to which initial liability comprised custodia as well as vis maior. Even if this was moderated in Labeo's times (exceptio was granted in the case of pirate attack or sea disaster), it still meant an entirely new shape of the contract, now very attractive for merchants, bankers and investors, who could feel secure from abuse on the part of entrepreneurs. Now, the custodia-based liability made major services such as sea transport, inland commercial haulage, shipping of goods, storing, or logistics much safer. It was enough to prove the contract was established, in fact a simple statement of the quantity and quality of goods was sufficient. In general, property had to be received by carriers or stablers, with some exceptions when their liability was extended even to the goods awaiting to be loaded. Consequently, not only reaching the destination, but also the safety of the merchants' goods was a contractual duty of a nauta, just as inn or stable keep-

\footnotetext{
6 D. 19.2.15.6, where Ulpianus refers to Caracalla's rescriptum.

7 "But even in case of locatio conductio operis, the nauta (here in the role of conductor) did not automatically incur this type of liability." Cf. Zimmermann (1990), 519.

8 D. 4.9.1.1: (...) et nisi hoc esse statutum, materia daretur cum furibus adversus eos recipiunt coeundi, cum ne nunc quidem abstineant huiusmodi fraudibus. Cf. Zimmermann (1990), 516.
} 
ers were responsible for the travellers' property. This understanding of liability in contracts was unlikely to make captains and ship-owners happy as it forced them to increase their care of the cargo, but it resulted in encouraging more investors to put their money in the business. ${ }^{9}$ The same applied to bankers, who would henceforth be more willing to lend money, even if the maritime loan (foenus nauticum) (see Biscardi, 1937, 350; Biscardi, 1947; Biscardi, 1978, 280 f.; Castresana Herrero, 1982, 76 f.; Purpura, 1987, 187 f.) did not allow them to claim it back if the enterprise failed (see Niczyporuk, 2013, 113-118; on loan prices and the problem of usury see Pikulska-Robaszkiewicz, 1999). Now a part of their risk was shifted to the nauta. As a result, loan prices for merchants were expected to decrease, but the sailors' rates could be an unpleasant surprise. Somebody had to pay for the reduced risk, and to a fair extent the maritime loan worked as an insurance policy. However, for the merchants who had not taken out such a loan, the liability of nauta had the same insurance effect, excluding exceptions described by Labeo. It could not cover the risk of a storm wrecking the ship, but it worked well against the safety problems on board, such as theft or damage. In modern days, this is a field for the insurance industry, but there was no classical insurance policy in the Antiquity, in itself a fascinating subject of disputes among Roman law scholars on sources such as the famous epigram composed by Martial regarding home insurance fraud committed by a Tongilian. ${ }^{10}$ Roman legal practice had of course the Rhodian law de iactu which - long before praetor's de nautae edict - provided a simple and equitable spread of the risk among everybody on board of the ship, if cargo had to be jettisoned in order to save the ship (cf. e.g. Osuchowski, 1950; Osuchowski, 1951; Płodzień, 1961; Reszczyński, 1981; Sondel, 1982). Republican lawyers adopted this rule into Roman law "not by the way of legal surgery, but in a most natural or homeopathic manner" (Zimmermann, 1990, 408). This is still in the modern use as a York-Antwerp rule, in which all parties involved in a sea venture must proportionately share any losses that result from sacrifices made to the cargo to save the remainder. Still, it applies to a rather limited number of cases and is usually covered by the insurance while strict contractual liability of entrepreneurs has a very wide modern use. In fact, it would be impossible not to have it. Regardless of whether the edict de nautae provided a direct custodial liability or whether parties had to conclude an additional receptum nautarum contract in a formal manner, it changed the way of doing business. Carriers, innkeepers, stable-

\footnotetext{
9 When the optional receptum was transferred into the unconditional guarantee to receive goods back is under dispute, but it might have happened in the post-classical period. See Brecht (1962), 114, and Kordasiewicz (2011), 8.

10 Roman law did not provide for any insurance contract, but it was known to legal practice. Martial wrote: Empta domus fuerat tibi, Tongiliane, ducentis: abstulit hanc nimium casus in urbe frequens. Conlatum est deciens. Rogo, non potes ipse uideri incendisse tuam, Tongiliane, domum? (Mart. 3.52). See Thomas (2009). In fact, using foenus nauticum reduced the risk of the travel and the increased interest rate (usually $33 \%$ ) was indeed an insurance premium while the banker was in the position of the insurance company.
} 
keepers in fact became insurers of their own services, albeit not unlimited. One might be inclined to state that it gave new life to the notion of a "professional", and represented a step in the history of capitalism. As this mode of liability was widely accepted in the ius commune and in the modern law, it would be justified to say that it shaped modern trade and commercial law. The subsequent step of comparable significance in the history of private law consisted in my opinion in the introduction of modern product liability rules and consumer protection rights.

\section{Secondary Sources}

Benincasa, Z. (2010a), Ryzyko związane z podróżami morskimi jako szczególnego rodzaju wkład niepieniężny do spółki w prawie rzymskim, Zeszyty Prawnicze [UKSW] 10.1, pp. 49-81.

Benincasa, Z. (2010b), Kontrakt spółki jako alternatywna dla pożyczki morskiej forma finansowania handlu morskiego, Zeszyty Prawnicze [UKSW] 10.2, pp. 61-91.

Benincasa, Z. (2011), Periculi pretium. Prawne aspekty ryzyka związanego z podróżami morskimi w starożytnym Rzymie (II w. p.n.e. - II w. n.e.), Warszawa.

Biscardi, A. (1937), La struttura classica del 'fenus nauticum', [in:] P. Ciapessoni (ed.), Studi in memoria di Aldo Albertoni, t. II, Diritto romano e Bizantino, Padova, pp. 345-371.

Biscardi, A. (1947), Actio pecuniae traiecticiae: contributo alla dottrina delle clausole penali, Siena (reeed. Torino 1974).

Biscardi, A. (1978), 'Pecunia traiecticia' e 'stipulatio poenae', Labeo 24, pp. 276-300.

Brecht, C. (1962), Zur Haftung der Schiffer im antiken Recht, München.

Bryant, E.E. (1895), The Reign of Antoninus Pius, Cambridge.

Casson, L. (1971), Ships and Seamanship in the Ancient World, Princeton.

Castresana Herrero, A. (1982), El préstamo marítimo griego y la pecunia traiecticia romana, Salamanca.

Cerami, P., di Porto, A. (2004), Diritto commerciale Romano. Profilo storico, Torino.

Chevallier, R. (1976), Roman Roads, London.

de Martino, F. (1980), Storia economica di Roma antica, Roma.

Derda, T., Markiewicz, T., Wipszycka, E. (eds.) (2007), Alexandria: The Auditoria of Kom el-Dikka and Late Antique Education, Warszawa.

Falenciak, J. (1956), Rodzaje umów o przewóz statkiem i ich prawne konstrukcje wedle świadectw rzymskich prawników klasycznych, Zeszyty Naukowe Uniwersytetu Wrocławskiego 6, pp. 55-98.

Földi, A. (1993), Anmerkungen zum Zusammenhang zwischen der Haftung 'ex recepto nautarum cauponum stabulariorum' und der Haftung für 'custodia', RIDA 40, pp. 265-291.

Grünewald, T. (2004), Bandits in the Roman Empire: Myth and Reality, [trans.] J. Drinkwater, Londyn-Nowy Jork.

Hölbl, G. (2003), A History of the Ptolemaic Empire, [trans.] T. Saavedra, London-New York.

Kordasiewicz, S. (2011), Zakres zastosowania edyktu 'nautae, caupones, stabularii ut recepta restituant', Zeszyty Prawnicze [USKW] 11.1, pp. 163-180.

Krzynówek, J. (2000), Geneza 'actio institoria' i 'exercitoria', [in:] A. Pikulska-Robaszkiewicz (ed.), Profesorowi Janowi Kodrębskiemu in memoriam, Łódź, pp. 169-196. 
Marzec, Ł. (2018), Wokół 'locatio-conductio'. Prawne aspekty przewozu i transportu morskiego w dawnym Rzymie, [in:] P. Cybula (ed.), Prawne aspekty podróży i turystyki - historia i wspótczesność. Prace poświęcone pamięci Profesora Janusza Sondla, Kraków, pp. 371-378.

Meyer-Termeer, A.J.M. (1978), Die Haftung der Schiffer im Griechischen und Römischen Recht, Zutphen.

Mielczarski, S. (1982), Dolina Dolnej Wisły w przeszłości (Lower Vistula Valley in the past), [in:] Dolina Dolnej Wisty, Wrocław-Warszawa-Kraków, pp. 61-79.

Niczyporuk, P. (2013), Bankierzy i operacje bankierskie w starożytnym Rzymie, Białystok.

Osuchowski, W. (1950), Appunti sul problema del 'iactus' in diritto romano, Iura 1, pp. 292-300.

Osuchowski, W. (1951), Ze studiów nad rzymskim prawem morskim. Uwagi nad zagadnieniem zrzutu morskiego, Czasopismo Prawno-Historyczne 3, pp. 41-52.

Palmirski, T. (2008), Kilka uwag na temat przyczyn wprowadzenia edyktów pretorskich »in factum adversus nautas caupones stabularios « oraz »furti adversus nautas caupones stabularios«, Krakowskie Studia z Historii Państwa i Prawa 2, pp. 33-41.

Palmirski, T. (ed.) (2014), Digesta Iustiniani. Digesta Justyniańskie. Tekst i przekład, vol. 1, Kraków.

Pikulska-Robaszkiewicz, A. (1999), Lichwa w państwie i prawie republikańskiego Rzymu, Łódź.

Płodzień, S. (1961), Lex Rhodia de iactu. Studium historycznoprawne z zakresu rzymskiego prawa handlowomorskiego, Lublin (reed. Lublin 2011).

Purpura, G. (1987), Ricerche in tema di prestito marittimo, ASGP 39, pp. 189-336.

Reszczyński, J. (1981), 'Actio oneris aversi' - D.19,2,31, Krakowskie Studia Prawnicze 14, pp. 19-36.

Rougé, J. (1966), Recherches sur l'organisation du commerce maritime en Méditerranée sous l'Empire romain, Paris.

Służewska, Z. (2007), 'Si tamen plures per se navem exerceant' - Kilka uwag o odpowiedzialności armatorów, Zeszyty Prawnicze [UKSW] 7.1, pp. 23-47.

Sondel, J. (1982), Z problematyki rzymskiego prawa morskiego, Czasopismo Prawno-Historyczne 34, pp. 139-144.

Thiel, J.H. (1946), Studies on the history of the Roman Sea-Power in Republican Times, Amsterdam.

Thomas, J.A.C. (1960), Carriage by Sea, RIDA 7, pp. 489-505.

Thomas, P.J. (2009), Insurance in Roman Law: 'Martialis Epigramatton' III 52, Journal of South African Law 2, pp. 264-273.

Torr, C. (1894), Ancient Ships, Cambridge.

Wiliński, A. (1960), D.19.2.31 und die Haftung des Schiffers im altrömischen Seetransport, Annales Universitatis Mariae Curie-Skłodowska sec. G Ius 7, pp. 353-376.

Wiliński, A. (1964), 'Actio oneris aversi', [in:] W. Osuchowski, M. Sośniarz, B. Walaszek (eds.), Rozprawy prawnicze. Księga pamiątkowa dla uczczenia pracy naukowej Kazimierza Przybyłowskiego, Warszawa-Kraków, pp. 451-465.

Wolny, M. (2007), 'Lex Claudia' a rozwój kariery politycznej Gajusza Flaminiusza, Studia Prawnicze 7, pp. 327-334.

Zimmermann, R. (1990), Law of Obligations. Roman Foundations of the Civilian Tradition, Cape Town.

Żeber, I. (2003), Kilka uwag o handlu morskim w prawie rzymskim, Acta Universitatis Vratislaviensis 2501, Prawo 285, pp. 43-51. 


\section{Łukasz Marzec}

\section{SOME REMARKS ON SEA TRANSPORT AND ITS LEGAL REGULATIONS IN ROMAN LAW}

The article examines the commercial and legal environment of sea transportation in Ancient Rome. The Author shows the size of Roman wheat trade. Carriage by sea required efficient legal tools. Locatio-conductio was the most common in use, but praetorian edict nautae, caupones stabularii ut recepta restituant changed the customers' situation. Roman law enabled equitable legal environment for sea trade, providing the base for modern international trade regulations. 


\author{
Benet Salway \\ University College of London \\ r.salway@ucl.ac.uk \\ ORCID 0000-0001-8070-4136 \\ https://doi.org/10.26881/gsp.2019.3.03
}

\title{
NAVICULARII, NAUCLEROI, AND THE ROMAN STATE
}

\section{Introduction}

The relatively restricted dossier of contemporary information relating to the development of associations of shippers (corpora naviculariorum) in the early Roman imperial period has recently received a significant addition. During their excavations in the summer of 2011 on the eastern slopes of Humeitepe hill at Balat in Turkey (the site of ancient Miletus), the team of the Ruhr-Universität Bochum unearthed a rectangular marble block elegantly inscribed with eighteen lines of Greek text addressed by the emperor Hadrian to the Milesians, granting permis-

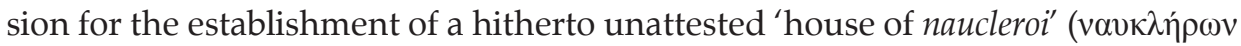
oĩ $\varsigma) .{ }^{1}$ This paper explores the possible implications of this text for our understanding of the nature of such associations of navicularii/naucleroi in the light of the scholarly debate on their function, especially in relation to Roman authorities.

This debate has been shaped inevitably by the pattern of the surviving sources concerning navicularii/naucleroi in the Roman world. ${ }^{2}$ For the period from the late republic to the mid-second century AD the sources are meagre and largely literary in character; it is only from the Antonine age onwards that technical legal literature, surviving through the sixth-century Digest of Justinian, can be joined with sporadic epigraphic testimony to form a clearer picture. Even then, the focus remains predominantly on the western Mediterranean and the shipping of goods to Rome. Moreover, the bulk of the Roman legal evidence, juristic and legisla-

1 Balat (Milet), Archaeological Museum, inv. HU 11.28.3; Ehrhardt and Günther (2013), $200=A E$ 2013, $1578=$ SEG 63, 974 .

2 Broekaert (2015), 216-250, $\mathrm{n}^{\text {os }} 383-443$, provides an alphabetical catalogue of navicularii and naucleri attested in Greek and Latin epigraphic sources. This partially, but not entirely, supersedes the catalogue of De Salvo (1991), 611-645, listing navicularii, nautae and other boatmen, and of their corpora, organized regionally. 
tive (Digest, Codex Theodosianus, Codex Iustinianus), derives from the third to sixth centuries $\mathrm{AD}$, when members of the associations of shippers became increasingly closely tied by obligation to the service of the needs of the Roman imperial state. So the evidence of the new text from Miletus helps to fill both a chronological and a geographical gap in our knowledge and it can, moreover, shed light on the mechanisms of and original purposes for establishing such associations.

\section{The inscription from Miletus}

Although the text is brief and breaks off before the end because of damage to the bottom of the stone, the main substance is preserved complete, as it is probably only the remains of the dating clause (day and month) and location of issue that have been lost:

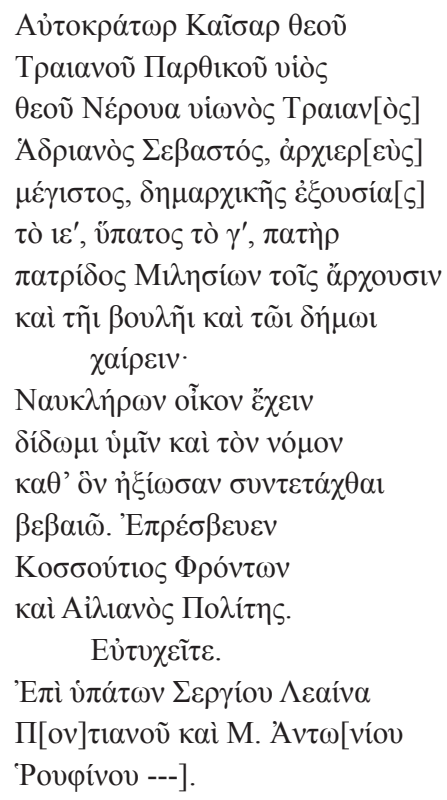

"The emperor Caesar Traianus Hadrianus Augustus, son of the divine Trajan Parthicus and grandson of the divine Nerva, pontifex maximus, with tribunician power for the $15^{\text {th }}$ time, consul for the $3^{\text {rd }}$ time, Pater Patriae (says) greetings to the magistrates, council, and to the people of the Milesians.

«I concede to you the possibility to form an association of shippers and I confirm the regulations according to which they have asked to be organised. Cossutius Fronto and Aelianus Polites carried out the embassy. Farewell!»

Under the consuls Sergius Laenas Pontianus and Marcus Anto[nius Rufinus ---]. (= AD 131)."

The text, which is carefully laid out, is carved on to an architectural block (125 $\mathrm{cm}$ high $\times 63 \mathrm{~cm}$ wide $\times 27 \mathrm{~cm}$ deep) that formed part of a gateway. That the 
inscription begins over a third the way down the front surface of the block (at $53 \mathrm{~cm}$ from the top) reflects the fact that it was carved onto part of a pre-existing edifice and positioned to facilitate its visibility. The inscribed text is not, of course, the authoritative copy of reference of the imperial grant but rather its public commemoration. The significance of the location is explained by the fact that this gateway would originally have opened onto the quayside of the east harbour of ancient Miletus, facing the estuary of the river Maeander and sheltered from the open sea of the Aegean by the promontory that survives as the now landlocked Humeitepe. The findspot of the inscription is thus plausibly close to the location of the meeting place of the beneficiaries of the grant, the naucleroi of Miletus, who no doubt paid for its carving.

\section{Petition and response}

The fact that the emperor's reply is conveyed in the form of a letter, rather than simply a subscription to a petition, reflects the fact that it responds to an approach from a public body not a private group or individual (Millar, 1977, 228-240 - imperial hearings, 240-252 - petitions and subscriptions). The dating of the imperial letter by the ordinary consuls of AD 131 (M. Sergius Octavianus Laenas Pontianus and M. Antonius Rufus), if it here faithfully reports the usage of the imperial chancery, is proper to the period from 1 January to 31 March, and certainly accords with the mention of the Hadrian's fifteenth tribunician power, which ran from August 130 to August 131 (on the chronology of Lassère, 2011, 1008, rather than Kienast [et al.], 2017, 124). The Milesian delegation will have met Hadrian somewhere in the East, during his travel from Alexandria, where he stayed in the spring of AD 131, to Athens, where he spent the winter of 131/132 and where the Milesians accorded him the honour of a statue. ${ }^{3}$ The addressing of Hadrian's letter to all three organs of civic government (magistrates, council, and popular assembly) shows that the ambassadors, whose names are duly recorded, approached the emperor to present a formal request on behalf of the city of Miletus. This accords with what else is known about these two ambassadors. Despite the fact that the names of both suggest their possession of Roman citizenship, whether intentionally or not, the two delegates also appear to represent two significant strands in the composition of the social élite of Roman Miletus: the descendants of Italian immigrants on the one hand and those of Greek heritage on the other. As the original editors of the inscription point out, the first ambassador, Cossutius Fronto, is very plausibly identical with Gaius Cossutius Fronto, one of the archontes (magistrates) who had overseen the erection of a public statue to Hadrian in Miletus in AD 123-124, ${ }^{4}$ and was likely a scion of a family of Cam-

\footnotetext{
${ }_{3} I G \mathrm{II}^{2}$ 3300. A further, unpublished, inscription (signaled in Kienast [et al.], 2017, 123) shows Hadrian to have arrived in Athens by September AD 131.

4 Milet I.7, $230=$ SEG 4, 425 .
} 
panian origin that had been active in the Greek East since the second century BC (Rawson, 1975, 38-40). The second ambassador, Aelianus Polites, may be the same as the Polites that minted coins for Miletus between AD 139 and 147, ${ }^{5}$ and may also be identified as the father or grandfather of Aelianus Asclepiades Polites, who headed a Milesian delegation to the emperors Marcus Aurelius and Commodus in Rome in $\mathrm{AD} 177 .^{6}$

The careful wording of Hadrian's reply makes it clear that his action in favour of Miletus has two parts. First he grants permission to 'you' (the magistrates, council, and people of Miletus) to have an association of naucleroi. Secondly he approves the regulation (vómos) according to which 'they' have asked to be organized. The 'they' here is clearly distinct from the civic authorities and may plausibly be identified with the prospective members of the association of naucleroi; though 'they' might also be the ambassadors, Fronto and Polites, who presented the case before the emperor. In fact, although effectively acting as the patrons of the naucleroi (van Nijf, 2003), and despite the high social standing of the ambassadors, the two possibilities (that 'they' are both the ambassadors and naucleroi) might not be entirely mutually exclusive (see further below). In any event, the process alluded to, attests to a reasonable degree of local autonomy in drafting the regulations.

The draft regulations no doubt defined criteria for membership, internal governance, and the identity of the religious cult that would likely have been a focus of any meetings. Epigraphic evidence from Latium and Rome shows that familiarity with the rules was a prerequisite for membership of the religious association of cultores of Diana and Antinous at Lanuvium and that the chief officers (curatores) of the collegium of negotiatores eborarii aut citriarii were responsible for checking the good character of new entrants. ${ }^{7}$ New members might be expected to pay entrance fees, as the award to the Ostian magistrate, Cn. Sentius Felix, of membership gratis of the navicularii maris Hadriatici demonstrates. ${ }^{8}$ The rules of the same association of worshippers of Diana and Antinous attest to a mechanism for the referral of complaints by individuals to the general assembly of members and papyrological evidence from Egypt shows that associations could enforce internal discipline by levying fines for misbehaviour. ${ }^{9}$ A papyrus from fifth-century Oxyrhynchus demonstrates how complaints against fellow associations members could be escalated to the relevant civic authorities..$^{10}$ The example of the Milesian naucleroi suggests that associations were generally incorporated within the legal authority of a specific civic community, in whose archives the regulations

\footnotetext{
5 RPC Online IV, 9086.

6 Milet VI.3, $1075=$ AE 1977, 801.

CIL XIV 2112, VI 33885; Broekaert (2011), 227.

CIL XIV 409 = ILS 6146; Broekaert (2013), 237-238, nº 406.

CIL XIV 2112, P.Mich. inv. 720; Broekaert (2011), 234.

10 P.Oxy. XVI 1943; Broekaert (2011), 234.
} 
of the association of will have been registered. This may have implications for our understanding of the patterns of geographic/ethnic naming that have been observed for associations of navicularii in the Roman world (see further below).

Whether or not the initiative for the proposal came spontaneously from the Milesians or was encouraged by the Roman provincial authorities (or even the emperor himself, as he passed through the region), the emperor's ready acceptance of the draft regulations of the association strongly suggests that they closely conformed to an accepted model. After all, permission to form a professional association could not be taken for granted.

\section{Associations in the Roman world}

The process of acquiring permission from the emperor to form the association of naucleroi at Miletus certainly accords with what we know about the regulation of voluntary associations in the provinces by the Roman authorities in this period (Cotter, 1996). The general attitude is already made clear famously in c. AD 111 by Hadrian's predecessor, Trajan. In reply to the enquiry of Pliny the Younger, governor of Pontus and Bithynia, about the possibility of establishing a collegium fabrorum of a hundred and fifty men at Nicomedia in order to fight fires, the emperor refuses on the grounds that the cities of Bithynia have had a history of being troubled by factions and because meetings of any sort have a tendency to become hetaeriae (political clubs). ${ }^{11}$ This general prohibition is confirmed by the jurist Gaius, writing in the mid-second century, in his commentary on the provincial edict (preserved at Justinian Digest: D. 3.4.1, pr.-1). Here he not only emphasises the multiple legal bases for the prohibition but also the narrow range of exceptions to the ban on associations (mostly at Rome), amongst whom he explicitly lists navicularii, who, he notes, also exist in the provinces:

D. 3.4.1. Gaius libro tertio ad edictum provinciale: pr. Neque societas neque collegium neque huiusmodi corpus passim omnibus habere conceditur: nam et legibus et senatus consultis et principalibus constitutionibus ea res coercetur. Paucis admodum in causis concessa sunt huiusmodi corpora: ut ecce vectigalium publicorum sociis permissum est corpus habere vel aurifodinarum vel argentifodinarum et salinarum. Item collegia Romae certa sunt, quorum corpus senatus consultis atque constitutionibus principalibus confirmatum est, veluti pistorum et quorundam aliorum, et naviculariorum, qui et in provinciis sunt. 1. Quibus autem permissum est corpus habere collegii societatis sive cuiusque alterius eorum nomine, proprium est ad exemplum rei publicae habere res communes, arcam communem et actorem sive syndicum, per quem tamquam in re publica, quod communiter agi fierique oporteat, agatur fiat. - "Gaius, On the Provincial Edict, Book 3, pr. Neither a societas, nor a collegium, nor corpus of such type is generally permitted for everyone to have: for the matter is governed by statutes, senatus consulta and imperial constitutions. Such corpora are permitted in only a few cases: the socii of the vectigalia publica (indirect taxes) are for instance permitted to avail themselves of a corpus, or (the socii) of gold or silver mines, and (socii) of salt pans. There are also

11 Plin. Ep. X 33-34. 
certain collegia in Rome, in each of which the corpus has been ratified by senatus consulta and imperial constitutions, such as (that) of the pistores (miller-bakers) and some others, and of the navicularii, who are also in the provinces. 1. Those permitted to form a corporate body (corpus) consisting of a collegium or societas, be it in the name of one or other of these, have the right on the pattern of a civic community to have common property, a common treasury, and an attorney or advocate through whom, as in a civic community, what should be transacted and done in common is transacted and done."

Although oĩkos ('house') is not a direct semantic parallel to the collegium, societas, or corpus of Gaius' Latin terminology, it seems reasonably secure to assume that the $v \alpha v \kappa \lambda \eta ́ \rho \omega v$ oĩ rather than simply a reference to the establishment of a physical meeting house

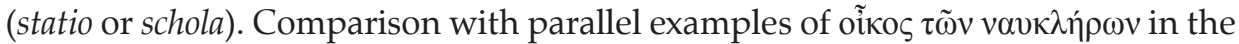
epigraphic record of the Aegean and Black Sea coasts demonstrates that, by the end of the first century AD, the term oĩ been the usage of the Hellenistic period) to designate the human association and not just its physical meeting place (De Salvo, 1992, 452-453; Bounegru, Bounegru,

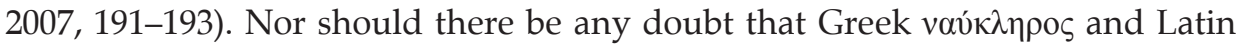
navicularius were equivalent as occupational titles by the Roman imperial period (De Salvo, 1992, 228-237; Broekaert, 2013, 220-222; cf. Rougé, 1966, 229-231). And, while navicularii might act personally as ship masters, who sailed with their cargo, or as ship owners, who were simply investors enjoying a profit, in essence the navicularius seems to be someone who uses a ship to offer certain services and retain the profits, whether or not he (or she) owns the vessel; that is, in modern English terms, a 'shipper' (Broekaert, 2013, 220). ${ }^{12}$ Thus, although navicularii have been considered of modest social standing in their local communities (Pleket, 1984, 10; Tran, 2006), it is no surprise, then, to find navicularii occupying a relatively eminent position in civic life. Thus in the amphitheatre of Nemausus (Nîmes), members of the navicularii of neighbouring Arelate (Arles) enjoyed reserved seat-

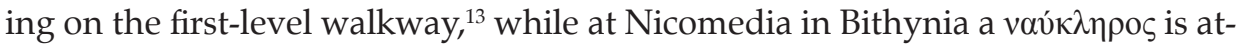

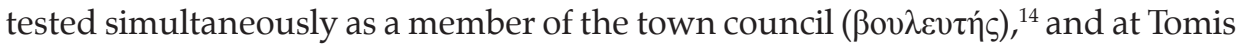
on the Black Sea another is attested as simultaneously occupying the position of local magistrate $(\beta \alpha \sigma i \lambda \varepsilon u ́ s) .{ }^{15}$ Nor did the role exclude respectable female participation, as the example of Aelia Isidora and Aelia Olympias, $\mu \alpha \tau \rho \tilde{\omega} v \alpha \iota \sigma \tau o \lambda \tilde{\alpha} \tau \alpha \iota$

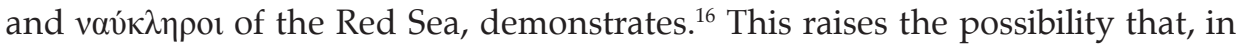
the case of Miletus, Cossutius Fronto and Aelianus Polites were not simply civic ambassadors or patrons of the prospective naucleroi but were actually themselves prospective members of the proposed association.

12 Cf. Palma (1975), 11, for whom the navicularius is always on board ship, and Herz (1988), 124, for whom he is purely an investor enjoying profit.

13 CIL XII 3318; van Nijf (1997), 234.

14 TAM IV.1, 304 = SEG 27, 828; De Salvo (1992), 622.

15 ISM II 186; De Salvo (1992), 626.

16 SEG VIII 703 = AE 1930, 53; De Salvo (1992), 231, 458-459. 


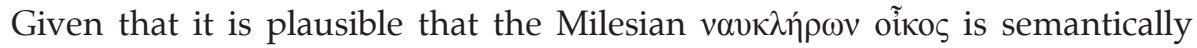
equivalent to a Latin corpus naviculariorum, this also raises the possibility that its juridical status might be assimilated to that enjoyed by the corpora naviculariorum known from the western provinces of the Empire. As we know from a passage of the third-century jurist Callistratus's work on hearings (preserved at Justinian Digest: D. 50.6.6, 3-6), active members of associations of navicularii that helped the supply (annona) of the City of Rome enjoyed the special privilege of immunity from local obligations (munera):

D. 50.6.6. Callistratus libro primo de cognitionibus: (...) 3. Negotiatores, qui annonam urbis adiuvant, item navicularii, qui annonae urbis serviunt, immunitatem a muneribus publicis consequuntur, quamdiu in eiusmodi actu sunt. Nam remuneranda pericula eorum, quin etiam exhortanda praemiis merito placuit, ut qui peregre muneribus et quidem publicis cum periculo et labore fungantur, a domesticis vexationibus et sumptibus liberentur: cum non sit alienum dicere etiam hos rei publicae causa, dum annonae urbis serviunt, abesse. 4. Immunitati, quae naviculariis praestatur, certa forma data est: quam immunitatem ipsi dumtaxat habent, non etiam liberis aut libertis eorum praestatur: idque principalibus constitutionibus declaratur. 5. Divus Hadrianus rescripsit immunitatem navium maritimarum dumtaxat habere, qui annonae urbis serviunt. 6. Licet in corpore naviculariorum quis sit, navem tamen vel naves non habeat nec omnia ei congruant, quae principalibus constitutionibus cauta sunt, non poterit privilegio na-

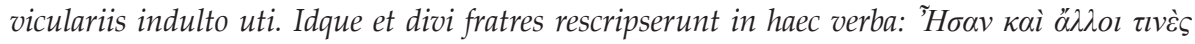

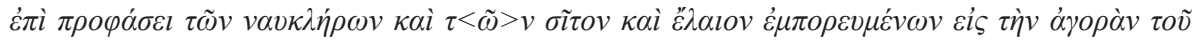

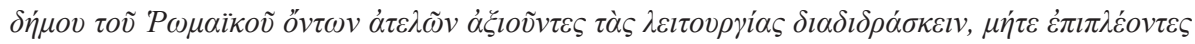

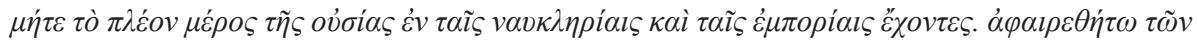

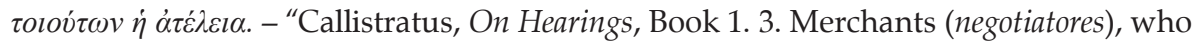
help the annona of the city (of Rome), likewise shippers (navicularii), who serve the annona of the city (of Rome), are entitled to an exemption for as long as they are occupied with it. Because it has rightly been established that their risks should be remunerated, and even encouraged by recompenses, so that those who perform risky and laborious munera and even munera publica outside their town, should be freed from domestic burdens and expense for there is nothing odd in saying that they too serve the annona of the city (of Rome) are absent in the public interest. 4. A particular clause is added to the immunitas given to the navicularii: 'which immunitas only they themselves have; it is not granted at the same time to their children or freedmen.' And this is made clear by imperial constitutions. 5 . The divine Hadrian replied that only those who serve the annona of the city (of Rome) have immunity on account of seagoing ships. 6. Although someone may be in a corpus of navicularii, if he has no ships and does not conform to all that is laid down by imperial constitutions, he cannot utilize the concession given to navicularii. And this the divine brothers also wrote in a rescript in these words: "There were also some other people who, while neither making voyages nor having the greater part of their resources in shipping or mercantile affairs, claimed to be exempt from munera on the pretext of being immune as naucleroi who convey both grain and oil to the market of the Roman people. Immunity is to be removed from such people." 


\section{Motivations for the establishment of the corpus naviculariorum at Miletos}

Reading the situation back from the legislation preserved in the Theodosian and Justinian Codes, under which the corpora naviculariorum were certainly obliged to supply Rome and Constantinople as an obligation (munus), ${ }_{1}^{17}$ past studies have emphasised the strategic interest of the earlier Roman authorities in fostering the corporations of shippers as key participants in the delivery of the annona to the city of Rome, and hence, tended to assume that imperial authorities were instrumental in encouraging the formation of these corporations (Sirks, 1991, 24-107; De Salvo, 1992, 15-22). A more recent trend has come to appreciate the commercial benefit that the formation of professional associations conferred on their members as well as on their customers. Studies by Koen Verboven, Wim Broekaert, Nicolas Tran, and Taco Terpstra have all proposed that professional associations protected their members interests and acted as lobbying groups but also, importantly, have explored how for negotiatores and navicularii the associations would have functioned thus as alternative or complementary networks to those of their own family members, slaves and freedmen (Broekaert, 2011; Tran, 2011; Verboven, 2011; Terpstra, 2013, 95-125). Membership enabled them to combat the impediments to efficient commerce inherent in the pre-industrial world. These associations facilitated the exchange of information on the reputation and financial resources of prospective economic partners, the drawing up of contracts with trustworthy agents, the seeking out financial investors, and the minimization of the risk of fraud and predatory conduct. It has additionally been proposed, in relation to the collegium of the nautae Ararici (river boatmen of the Saône) and that of the negotiatores vinarii Luguduni in canabis consistentes (the wine traders of Lyon) benefitted economically and commercially from having patrons in common, through whom disputes might be resolved without the need of costly and time-consuming court proceedings. ${ }^{18}$ The most famous example of successful lobbying by associations of shippers is commemorated in the letter, preserved on a bronze disc found in Beirut, of a certain Iulianus (probably the praefectus annonae c. AD 198-203) to the navicularii marini Arelatenses quinque corporum, after a successful case prompted by their collective action in the form of a decree (decretum) of the association (now lost). ${ }^{19}$ Their threat to withdraw their co-operation in shipping the annona was successful in producing the reprimand issued to a lower procurator, laying down how his staff should behave in future:

[Cl(audius) I]ulianus naviculariis / [mar]inis Arelatensibus quinque / [co]rporum salutem. / [Qu]id lecto decreto vestro scripserim / [[---]S[---]] proc(uratori) Augg(ustorum) e(gregio) v(iro) subi / [e]ci iussi. Opto felicissimi bene valeatis.

\footnotetext{
17 C. Th. 13.5-6; C. 11.2-4. Cracco Ruggini (1976); De Salvo (1992), 483-598.

18 CIL XIII 2020, VI 29722; Hasegawa (2015).

19 CIL III 14165, 8, cf. III p. 2328, 78 = ILS $6987=$ AE 1998, 876 = 2006, 1580, col. I; see most recently Virlouvet (2004) and Corbier (2006).
} 
E(xemplum) e(pistulae):

Exemplum decreti naviculariorum ma / rinorum Arelatensium quinque cor/ porum, item eorum quae aput me acta / sunt, subieci. Et cum eadem querella la/tius procedat, ceteris etiam imploranti / bus auxilium aequitatis, cum quadam de/nuntiatione cessaturi propediem obsequi / si permaneat iniuria peto, ut tam indemni/tati rationis quam securitati hominum / qui annonae deserviunt consulatur, / inprimi charactere regulas ferreas et / adplicari prosecutores ex officio tuo iu/beas qui in urbe pondus quo susce/perint tradant. - "[Claudius I] ulianus to the navicularii marini of Arles belonging to the five corpora greeting! What I wrote, after reading your decree, to (name deleted), vir egregius, procurator of the emperors, I have commanded to be appended. I wish, fortunate people, that you may prosper!

Copy of the letter:

I have appended below a copy of the decree of the navicularii marini of Arles belonging to the five corpora and likewise (a copy) of the documents from the court case conducted before me. And should the same dispute continue further, and the others (sc. the navicularii) appeal to justice with what amounts to a formal warning that they will soon cease to comply with their obligations, and if the injustice continues, I request that provision be made for both a guarantee against financial loss in the books and for exoneration of the people providing services for the annona, and that you order the marking of an indelible scale on the (inner sides of the) ship, and that escorts from your staff be provided, who will hand over (details of) the cargo weight that they loaded."

On a more modest scale perhaps, Nicolas Tran has argued that successful lobbying by the nautae Rhodanici (boatmen of the river Rhône) for some unidentified benefit lies behind their celebration of Hadrian early in his reign as indulgentissimus princeps on a statue base from Tournon-sur-Ardèche in Gallia Narbonensis. ${ }^{20}$ Tran argues that the benefit might plausibly relate to an advantage in the management of commercial navigation and taxation.

So there is a strong argument that commercial and strategic advantage was sufficient motive for provincial shippers to wish to form themselves into associations. Obviously, if Hadrian considered the naucleroi of Miletus to be a corpus naviculariorum serving the annona of Rome, then a very tangible benefit (immunity from local civic obligations) would follow. However, if not, then a further specific motivation for the shippers of Miletus petitioning Hadrian may be found. We might imagine that they hoped that an approved corpus naviculariorum could act as platform for lobbying the emperor to exercise his indulgentia, as he had done towards the nautae of the Rhône, perhaps by granting them an exemption from the Romans' $2.5 \%$ tax on goods passing through Asian ports (the quadragesima portuum Asiae), for which there was a collection station established at Miletus (Cottier [et al.], 2008; Herrmann, 2016).

On the other hand, we must consider what motivations might have persuaded Hadrian, against the background of the general prohibition, to permit the for-

$\overline{20}$ CIL XII 1797: Imp. Caes. divi / Traiani Parthici / fil. divi Nervae / nepoti Traiano / Hadriano Aug. / pontif. max. trib. / potest. III cos. III / n. Rhodanici / indulgentissimo / principi. (AD 118/119). Tran (2011). 
mation of this particular corpus. In the same way that the collegial practices of the associations helped to enforce honest commercial behaviour and guarantee the reliability of their members to the benefit of other traders so this was also to the advantage of Roman authorities in the event that they wished to make contracts with members of such corporations for state purposes. It is fairly easy to identify the purposes for which Roman authorities wished to contract shippers in the western Mediterranean and from Alexandria (the annona of the city) and to some extent also those attested in the Black Sea (supply of the army on the Danube). The reason for recognising a corpus naviculariorum at Miletus is less immediately obvious in terms of the supply of the needs of the population of Rome or the provincial armies. However, there is good evidence that Miletus acted as an entrepôt for the shipment of marble from the imperially owned quarries in inland Asia Minor, specifically those of Phrygia, which provided the marmor Phrygium, known today as pavonazetto (Russell, 2013, 47-50); though it should not be forgotten that Phrygia was also famous for the textiles produced at Hierapolis and Laodicea (Thonemann, 2011, 185-190). Quarries at Docimium and in the Upper Tembris Valley are known to have been under imperial control (Fant, 1989; Hirt, 2010; Russell, 2013, 38-94, esp. 43-50), and the area was managed by procurators (Vitale (2015), though private contractors were also involved (Pensabene, 2015, 575-593). Given that the river Maeander was not navigable further upstream than the area of Laodicea and Hierapolis, the marble from the quarries to the north east must have come overland via Apamea, lake Sanoas, and Colossae, to Laodicea (Fant, 1989, 6-41; Pensabene, 2013, 360-387; Russell, 2013, 138-139). The significance of the river for transport of the marble down to the Aegean and on to Rome, may be reflected in the pattern of activity of a certain imperial freedman, Chresimus, attested as procurator a marmoribus or a lapicidarum in Asia between the reigns of Domitian and Trajan. Aside from Ephesus, the centre of the imperial administration of the entire province of Asia, he is otherwise recorded on three inscriptions from different locations in the Maeander valley, including his possible final resting place at Miletus. ${ }^{21}$ Given the importance of the supply of marble to Hadrian's building projects in the city of Rome and elsewhere, this emperor may have considered the establishment of a corpus naviculariorum at Ephesus of real benefit. Certainly changes in the styles of the control inscriptions carved at the Phrygian quarries suggest a reorganization under Hadrian in the later 130s (Fant, 1989, $\mathrm{n}^{\text {os }} 40$, 127; Hirt, 2010, 328-331).

21 IK 13, 856, Ephesos (imperial dedication to uncertain emperor); $A E$ 1988, $1028=$ SEG 38, $1073=I K$ 35, 929 = RRMAM 3.5, 111a, Mylasa (AD 92/97): vias restituit / [per] Chresimum lib. pro[cur. / a] mar-

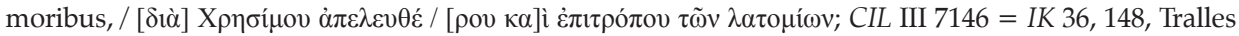
(under Nerva): [Chr]esimus [Aug. l. proc. lapi / cidin]arum; Milet VI.2, 524 = SEG 38, 1215 (possibly his

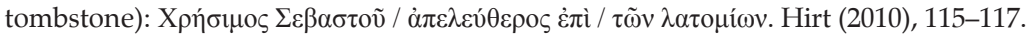




\section{The significance of place of incorporation}

Before the discovery of the new text, the only corporations of naucleroi known from the province of Asia were located at Smyrna (or Ephesos?), and Iasos. ${ }^{22}$ The majority of corporations of shippers are named after a specific community, as for example on the mosaic floors of the various stationes around the so-called «Piazzale delle Corporazione» at Ostia. ${ }^{23}$ On the pattern of the titles of these other corporations (De Salvo, 1991, 614-621), it is reasonable to imagine that the Mile-

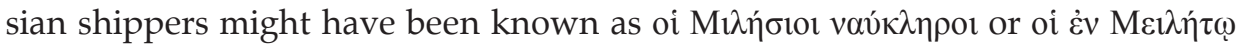

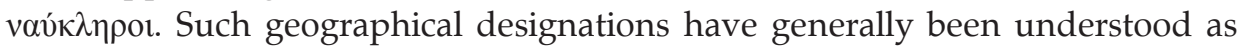
reflecting the origin of the shippers, even though it is clear from a several examples that these corporations were open to members who did not share the geographical origin. ${ }^{24}$ The new evidence from Miletus reminds us of an alternative significance of the geographical titles: as indicators of the city in which the corporation is registered. In most instances, of course, there will have been a large overlap between the origin of the majority of the members and the city in which the association was incorporated. This is eminently plausible for the navicularii Karthaginienses, the Sabrathenses, the Narbonenses, etc. who maintained stationes at Ostia. But what of the corpus naviculariorum maris Hadriatici, attested by half a dozen inscriptions, mostly from Ostia? Lietta de Salvo assumed that their headquarters were located at Aquileia, the chief port of the Adriatic (De Salvo, 1992, 436). However, in this case might the unspecific description reflect the nature of a group of shippers whose common interest was in doing business to various destinations in the Adriatic but whose central location was Ostia not Aquileia? The discovery at Ostia of an altar dedicated by one of the senior officers of the association to the genius corporis naviculariorum [maris] Had[r]iatici may confirm this hypothesis, given that it may have embellished the schola of the corporation. ${ }^{25}$ The place of incorporation of an association of shippers need not have had much real impact on daily business but will have been significant in relation to its common property, which might include slaves. For the status of freed slaves would varying according to the nature of the community in which the owning association was incorporated. The status of slaves freed by an association incorporated in a peregrine community, such as Miletus, would be dictated by the local rules of that community, while slaves freed by associations incorporated in Roman com-

22 CIG 5888 = IG XIV 1052 = IGR I 147 = IGUR 26, Rome (AD 154); BCH 1894, $21 \mathrm{n}^{\circ}$ 11, Iasos (undated). De Salvo (1991), 452.

23 CIL XIV 4549; De Salvo (1991), 391-395, 612-613; Terpstra (2013), 117-126.

24 CIL XIII, 1942 = ILS 7029: Q. Capitonius Probatus Senior, domo Roma, sevir Augustalis Luguduni et Puteolis, navicularius marinus (at Lyon?); Broekaert (2013), 228, n 392. CIL XII $982=$ ILS 6986: M. Frontonius Euporus, sevir Augustalis coloniae Iuliae Aug. Aquis Sextis, navicularius maritimus Arel(atis), curator eiusdem corporis (probably from Nîmes); Broekaert (2013), 231-232, nº 396.

25 AE 1987, 192: Genio / corporis / naviculariorum / [maris] Had[r]iatici / [---]s T. f. Ser. / [---]sus / [quinq.] perpetuus / [---]i poni iussit. 
munities, such as the Quinque corpora registered in the Colonia Iulia Paterna Arelate Sextanorum (founded by Caesar in 46 BC for veterans of his Sixth Legion) or the navicularii maris Hadriatici at Ostia, would become Roman citizens. The residents of Ostia, Hadriaticus Hermias and Hadriaticus Felix, are plausibly identified as such former slaves of the navicularii maris Hadriatici. ${ }^{26}$

\section{Conclusions}

Despite its brevity, Hadrian's letter to the Milesians, concerning the establishment of a corpus of naucleroi there, sheds new light on the relationship between central imperial authority and local regulation, through the technicalities of the process of obtaining permission for a professional association in a provincial context. In this case the chances of success in obtaining permission may have been increased by the mutual benefit identifiable for both local shippers and Roman authorities by establishing a corpus naviculariorum at Miletus in the early second century AD.

\section{Secondary Sources}

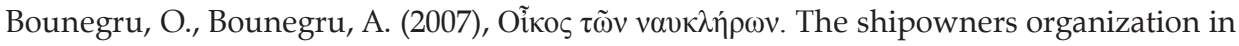
the Pontic and Aegean area, [in:] Acta XII Congressus Internationalis Epigraphiae Graecae et Latinae: Provinciae Imperii Romani inscriptionibus descriptae, Barcelona, 3-8 Septembris 2002, Barcelona, vol. 1, pp. 191-196.

Broekaert, W. (2011), Partners in business: Roman merchants and the potential advantages of being a "collegiatus", AncSoc 41, pp. 221-256.

Broekaert, W. (2013), Navicularii et Negotiantes: A Prosopographical Study of Roman Merchants and Shippers, Rahden.

Corbier, M. (2006), Les mesures et les hommes: les naviculaires d'Arles et leurs «règles de fer», [in:] eadem, Donner à voir, donner à lire. Mémoire et communication dans la Rome ancienne, Paris, pp. 233-256.

Cotter, W. (1996), The collegia and Roman law: state restrictions on voluntary associations 64 BC-200 CE, [in:] J.S. Kloppenborg, S.G. Wilson (eds.), Voluntary Associations in the Graeco-Roman World, London, pp. 74-89.

Cottier, M., Crawford, M.H., Crowther, C.V., Ferrary, J.-L. Levick, B.M., Salomies, O., Wörrle, M. (eds.) (2008), The Customs Law of Asia, Oxford.

Cracco Ruggini, L. (1976), Collegium e corpus: la politica economica nella legislazione e nelle prassi, [in:] G.G. Archi (ed.), Istituzioni giuridiche e realtà politiche nel tardo impero (III-IV sec. d. C.). Atti di un incontro tra storici e giuristi (Firenze 2-4 maggio 1974), Milano, pp. 63-94.

De Salvo, L. (1992), Economia private e pubblici servizi nell'impero romano. I corpora naviculariorum, Messina.

Ehrhardt, N., Günther, W. (2013), Hadrian, Milet und die Korporation der milesischen Schiffseigner. Zu einem neu gefundenen kaiserlichen Schreiben, Chiron 43, pp. 199-220.

${ }^{26}$ CIL XIV $4562=A E$ 1919, 65; CIL XIV $4569=$ AE 1928, 123. 
Fant, J.C. (1989), Cavum Antrum Phrygiae. The Organization and Operations of the Roman Imperial Marble Quarries in Phrygia, Oxford.

Hasegawa, T. (2015), L'union de collèges professionels de Lyon par le biais de patrons communs: le moyen le plus prompt de résoudre des affaires, [in:] L. Rossi, H. Rougier (eds.), De la production à la consummation: le temps en jeu dans la Méditerranée antique = Pallas 99, pp. 227-243.

Herrmann, P. (2016), Zur römischen Zollstation in Milet, [in:] idem, Kleinasien im Spiegel epigraphischer Zeugnisse. Ausgewählte kleine Schriften, Berlin, pp. 491-496.

Herz, P. (1988), Studien zur römischen Wirtschaftsgesetzgebung. Die Lebensmittelversorgung, Stuttgart.

Hirt, A.M. (2010), Imperial Mines and Quarries in the Roman World: Organizational Aspects, $27 B C-A D$ 235, Oxford.

Kienast, D., Eck, W., Heil, M. (2017), Römische Kaisertabelle: Grundzüge einer römischen Kaiserchronologie, Darmstadt.

Lassère, J.-M. (2011), Manuel d'épigraphie romaine, Paris.

Millar, F.G.B. (1977), The Emperor in the Roman World (31 BC-AD 337), London.

Nijf, O.M. van (1997), The Civic World of Professional Associations in the Roman East, Amsterdam.

Nijf, O.M. van (2003), Les élites comme patrons des associations professionnelles dans l'orient romain, [in:] M. Cébeillac-Gervasoni, L. Lamoine (eds.), Les élites et leurs facettes Les élites locales dans le monde hellénistique et romain. Actes du colloque international de Clermont-Ferrand, 24-26 novembre 2000, Rome, pp. 307-321.

Palma, A. (1975), L'evoluzione del naviculariato tra il I ed il III sec. d. C., AAN 86, pp. 7-31.

Pensabene, P. (2013), I marmi nella Roma antica, Rome.

Pensabene, P. (2015), Marmi pubblici e marmi private: note in margine ad un recente volume di Ben Russell, ArchClass n.s. 5, pp. 575-593.

Pleket, H.W. (1984), Urban elites and the economy in the Greek cities of the Roman Empire, MBAH III.1, pp. 11-15.

Rawson, E. (1975), Architecture and sculpture: the activities of the Cossutii, PBSR 43, pp. $36-47$.

Rougé, J. (1966), Recherches sur l'organisation du commerce maritime en Méditerranée sous l'Empire romain, Paris.

Russell, B. (2013), The Economics of the Roman Stone Trade, Oxford.

Sirks, A.J.B. (1991), Food for Rome: The Legal Structure of the Transportation and Processing of Supplies for the Imperial Distributions in Rome and Constantinople, Amsterdam.

Terpstra, T.T. (2013), Trading Communities in the Roman world: A Micro-Economic and Institutional Perspective, Leiden.

Thonemann, P. (2011), The Maeander Valley: A Historical Geography from Antiquity to Byzantium, Cambridge.

Tran, N. (2006), Les membres des associations romaines: le rang social des collegiati en Italie et en Gaules, sous le Haut-Empire, Rome.

Tran, N. (2011), Les collèges professionnels romains: «clubs» ou «corporations»? L'exemple de la Vallée du Rhône et de CIL XII 1797 (Tournon-sur-Rhône, Ardèche), AncSoc 41, pp. 197-219.

Verboven, K. (2011), Introduction: professional collegia: guilds or social clubs? , AncSoc 41, pp. 187-195. 
Virlouvet, C. (2004), Les naviculaires d'Arles à propos de l'inscription provenant de Beyrouth, MEFRA 116.1, pp. 327-370.

Vitale, M. (2015), Imperial Phrygia: a "procuratorial province" governed by liberti Augusti?, Philia 1, pp. 33-45.

\section{Benet Salway}

\section{NAVICULARII, NAUCLEROI, AND THE ROMAN STATE}

In a recently discovered letter the Roman emperor Hadrian grants to the civic authorities of the port of Miletus permission to establish a corporation of shippers. Confronting this new text with the relevant legal and other epigraphic evidence, this paper explores the implications of this text for our understanding of the process for and, the motivations behind, setting up such a corporation. 